\title{
Challenges for optimizing social protection programmes and reducing vulnerability in Latin America and the Caribbean ${ }^{1}$
}

\author{
Javier Bronfman $\mathrm{H}$.
}

\begin{abstract}
This article provides a reflexive analysis of the design and implementation of social protection systems and anti-poverty programmes in Latin America and the Caribbean. It focuses particularly on the expansion of the conditional cash transfer and non-contributory pension programmes implemented over recent decades. The aim of this study is to distil policy lessons and foster debate on the challenges and opportunities that the 2030 Agenda for Sustainable Development currently poses for social protection systems. The article argues that more of the same will not be enough to maintain progress and achieve higher levels of development in the future. Using examples, the discussion turns to the challenges lying ahead under the paradigm of the 2030 Agenda for Sustainable Development. These include excluded groups, life cycle needs, better coordination between sectors and fiscal constraints. It ends with a number of questions to foster discussion and a conclusion with policy recommendations.
\end{abstract}

\section{Keywords}

Social security, poverty mitigation, social policy, 2030 Agenda for Sustainable Development, income, pensions, programmes of action, administrative reform, equality, Latin America and the Caribbean

\section{JEL classification}

$$
\text { I3, } \mathrm{HO}, \mathrm{H} 4
$$

\section{Author}

Javier Bronfman $\mathrm{H}$. holds a degree in Business Administration and a doctorate in Public Administration and Policy from American University, United States, and is Assistant Lecturer at the Faculty of Economics and Business at Andrés Bello University, Chile. Email: javier.bronfman@unab.cl.

The author is grateful for comments on this article received from staff of the United Nations Development Programme (UNDP) and colleagues at the School of Government of Universidad Adolfo Ibáñez, Chile, to which the author was affiliated when this article was accepted for publication. Any remaining errors are the author's own. 


\section{Introduction}

This article provides an analysis of the design and implementation of social protection systems and anti-poverty programmes in Latin America and the Caribbean, in order to learn lessons from the past and improve future policy. The analysis aims to distil policy messages and foster a rich discussion on the challenges and opportunities for a new generation of social protection systems in light of the 2030 Agenda for Sustainable Development.

Although there are various definitions of social protection, all of them agree that social protection systems involve policies and programmes to address poverty and vulnerability. The United Nations Development Programme (UNDP) defines social protection systems operationally as systems that: provide contributory or non-contributory forms of income support that reduce and prevent poverty; ensure access to basic social services to all, especially for groups that are traditionally vulnerable or excluded; stimulate productive inclusion through the development of capabilities, skills, rights and opportunities for the poor and excluded; build resilience and protect people against the risks of livelihood shocks throughout their lifecycle; and help remove structural barriers, including barriers within the household, that prevent people from achieving well-being. (UNDP, 2016c p. 16).

To address inequality in its multiple forms, social protection systems consist of three elements: social assistance, social insurance, and labour market policies (Barrientos, 2011). Inequality can be identified through a matrix consisting of four axes: (i) socioeconomic status; (ii) gender, race and ethnic origin; (iii) stages of the lifecycle, and (iv) territorial heterogeneities (ECLAC, 2016, p. 16). These variables are naturally interconnected; it is easy to see how increasing one can affect the others.

Social protection systems have become prevalent worldwide as a way to reduce and prevent poverty by helping people mitigate their exposure to risks and absorb negative shocks. They have also incorporated human capital investments, promoting human development and breaking free from the existing poverty traps. However, several challenges remain. While social protection systems have potential, the existing programmes are not strong enough to ensure the targets of the Sustainable Development Goals (SDGs) are attained.

Reforms are needed to underpin multidimensional progress and achieve sustainable development. Social protection needs to be expanded and a minimum floor of benefits guaranteed, to mitigate life-cycle risks and protect the region's expanding vulnerable population. Attention also needs to be paid to historically excluded or stigmatized groups (for example indigenous populations, women, and lesbian, gay, bisexual, transgender and intersex persons (LGBTI), addressing structural factors limiting expansion and considering the environment throughout the reform process.

The next section will contextualize Latin America and the Caribbean's regional development status by presenting data on development trends over the past two decades. Section III briefly discusses past social protection reforms, with emphasis on the expansion of conditional cash-transfer (CCT) and non-contributory pension programmes that have been implemented over the past two decades. Section IV discusses a set of key challenges facing the social protection system. The final section concludes.

\section{Latin America and the Caribbean: past achievements and development trends}

Since the Millennium Declaration in 2000, which defined the Millennium Development Goals, Latin America and the Caribbean has thrived. The region has seen major achievements in terms of poverty reduction, gender parity, improved health status, and overall well-being. According to the Millennium Development Goals Report 2015, Latin America and the Caribbean achieved the 
target of halving the extreme poverty rate. The proportion of people living on less than US $\$ 1.25 \mathrm{a}$ day fell from $13 \%$ in 1990 to $4 \%$ in 2015. Access to safe drinking water increased 10 percentage points to $95 \%$, and the number of people without access to basic sanitation has been nearly halved (United Nations, 2015).

Achievements also abound in health outcomes and access to services. The rate of malnutrition fell from $15 \%$ in 1990 to $6 \%$ in 2015 . The under-fives mortality rate dropped sharply, surpassing the two-thirds reduction target. In contrast, maternal mortality remains high in many of the region's countries (United Nations, 2015). Progress has also been made in controlling the HIV/AIDS epidemic; and HIV infections among children have declined as a result of programmes to prevent mother-to-child transmission. Among adults, however, the rate of new infections increased by 3\% between 2010 and 2015, with infections still concentrated among gay men, transgender people, sex workers (UNAIDS, 2016), and young people in the Caribbean. School enrolment and labour market participation have both nearly attained gender parity.

However, in most countries there are groups for whom this is not the reality, owing to discrimination on gender, ethnicity, and race. Indigenous and Afrodescendent people, for example, have faced discrimination since the colonization period (ECLAC and others, 2018). Several programmes and initiatives have been put in place since 1948 to recognize their equal rights; nonetheless, these goals remain a key element of the social inequality matrix (ECLAC, 2016). While there has been a focus on gathering better data on these groups, they are still underrepresented in public institutions and overrepresented in the poorest deciles of the income distribution. Moreover, owing to territorial segregation, they often lack access to basic services (ECLAC, 2016); and they are also among the least educated groups, despite efforts to introduce bilingual education in the 1970s (ECLAC, 2016). Other minorities, such as transgender people, are denied legal identification documents that recognize their gender identity, thus preventing them from completing basic education. ${ }^{2}$

Notably, the Latin American and Caribbean region has more girls than boys enrolled in secondary education - a unique achievement worldwide. Nonetheless, educational achievement does not always translate into opportunities in terms of formal and high-quality employment. Despite the increase in female labour market participation, women still face higher rates of unemployment, underemployment, discrimination, and informality - especially among indigenous people, who also tend to suffer wider gender gaps in the first place. While Latin America and the Caribbean enjoys the highest female representation in parliament among developing regions of the world, ${ }^{3}$ women are still underrepresented. They are also more likely to live in poverty than men; the ratio of women to men in poor households rose from 108 women per 100 men in 1997 to 117 per 100 in 2012 (United Nations, 2015).

It is also important to recognize that regional successes do not tell the whole story. Reductions in extreme poverty have not been uniform across and within countries or subregions. While extreme poverty in the region as a whole decreased from 12\% to 4\% between 1990 and 2015, Caribbean countries saw a reduction of 11 percentage points during that time, reaching a level of $22 \%$ in 2015 . While the latest data report the prevalence of undernourishment regionwide is below $5 \%$, the rate in the Caribbean is $20 \%$.

Since 1990, monetary poverty has gradually declined for most Latin American and Caribbean countries. However, in some cases (such as Colombia, Mexico, Peru and the Plurinational State of Bolivia) poverty increased between 1990 and 2000, before declining until 2015. In Belize, between 2002 and 2009 , overall and extreme poverty increased from $34 \%$ to $42 \%$ and from $11 \%$ to $16 \%$ respectively

\footnotetext{
2 The fact that a majority of transgender Latin Americans have not completed a basic level of education conflicts with the guarantee for primary education (article 13, para. 2(a) of the International Covenant on Economic, Social and Cultural Rights) (Rachid and Massenzio, 2014, p. 31).

3 Although it is still only $27 \%$.
} 
(Government of Belize/CDB, 2010). ${ }^{4}$ Multidimensional poverty rates also vary significantly between countries. ${ }^{5}$ In Haiti, $50 \%$ of the population live in multidimensional poverty; in Barbados and Saint Lucia, the figure is less than $1 \%$.

Even within countries, multidimensional poverty is more prevalent among specific groups. Two recent studies report higher prevalence among the indigenous populations of Chile (Bronfman Horovitz, 2014; Bronfman and Hadad, 2016). Both estimate that the Mapuche people ${ }^{6}$ in Chile suffer much higher rates of multidimensional poverty than the rest of the population, even when controlling for their living standards (Bronfman and Hadad 2016). ${ }^{7}$ These findings support the idea that racial minorities continue to suffer social and economic inequalities that are rooted in the past. These groups need greater recognition, especially in statistical data, to help protect their rights. Brazil, Ecuador and the Plurinational State of Bolivia have recently moved in the right direction by recognizing indigenous people's rights in their respective constitutions (ECLAC and others, 2018).

Many of the 72 million people lifted out of poverty in Latin America and the Caribbean over the past decade have become vulnerable to poverty once more. ${ }^{8}$ According to the latest UNDP estimations, 38.4\% of the region's population could fall into poverty in the near future (UNDP, 2016a). This vulnerability is not simply a matter of income, but involves other development indicators as well, possibly reflecting social discrimination (López-Calva and others 2014; UNDP, 2016a). ${ }^{9}$ Much of the population faces high levels of exposure to both idiosyncratic and aggregate shocks -a major concern given the region's high prevalence of environmental shocks and natural disasters. The Latin American and Caribbean region has seen steady growth in the number and severity of natural disasters over the past 50 years (Vargas, 2015), particularly in the Caribbean subregion. Recent events have resulted in significant costs in terms of human lives and economic activity, especially in the agriculture and tourism sectors. In the absence of strong safety nets and access to coping mechanisms, these shocks have the potential to push large swathes of the population back in poverty, thereby giving up previous achievements.

Nonetheless, the countries are recognizing the existing environmental challenges. Many of the region's countries have based their development on the extraction of non-renewable resources - minerals and fossil fuels - while ignoring sustainability and environmental protection. The results have been environmental degradation and ecosystem fragility, including the endangering of valuable natural reserves. This spurs a socioenvironmental conflict that disproportionately affects the indigenous people who live in these territories (ECLAC and others, 2018).

4 The poverty figures for Belize are less recent owing to a data availability problem common to the region, particularly in the Caribbean countries.

5 In an effort to understand poverty beyond income and recognize that both development and poverty are multidimensional, UNDP, in partnership with the Oxford Poverty and Human Development Initiative, published its first International Multidimensional Poverty Index (MPI) in the 2010 Human Development Report (UNDP, 2010). This novel measure complements income poverty by considering simultaneous deprivations along three dimensions (education, health, and standard of living).

6 The Mapuche are the largest indigenous group in Chile, representing $7.5 \%$ of the total population.

7 The methodology tailored to estimate the rural Mapuche MPI accounted for differences in living standards by not considering dirt floors as a deprivation and changing the cut-off for water-access deprivation.

8 Several studies have examined vulnerability to poverty in the light of recent methodological developments and availability of data. Cruces and others (2010) provide vulnerability-to-poverty estimates for 18 Latin American and Caribbean countries between the early 1990s and mid-2000s. Using different international poverty lines, their results indicate a much higher rate of vulnerability than actual poverty in Latin America. While aggregate vulnerability in the region has decreased over time, individual countries vary widely, and some are left behind entirely. Using household survey panel data, Bronfman Horovitz (2014) explores poverty dynamics in Chile to reveal a high level of vulnerability. For each of the years surveyed (1996, 2001 and 2006), vulnerability significantly surpasses the prevailing poverty estimates.

9 LGBT people face the same socioeconomic challenges as others who share their sex, race, ethnicity, age, and disability status. But they also face unique obstacles owing their sexual orientation and gender identity. These include higher risks of youth homelessness, harassment and discrimination at school and in the workplace, and denial of the economic benefits of marriage (Sears and Badgett, 2012). 
Governments must recognize the importance of social protection systems as a tool to attain the Sustainable Development Goals. Designing and implementing a social protection floor for the poorest and most vulnerable has become essential, particularly in the context of economic slowdown. Strong, inclusive, and wide-ranging social protection systems need to be built to overcome these difficulties; this can only be achieved if consideration of both social and environmental challenges is at the core of the new generation of policies and programmes.

\section{Social protection systems in Latin America and the Caribbean: past and recent developments}

As noted above, social protection systems consist of three elements: social assistance, social insurance, and labour market policies. They aim to reduce poverty and vulnerability and are generally financed from general revenues. Examples include conditional and unconditional cash transfers, direct subsidies, non-contributory pensions, and services that are free at the point of use. In contrast social insurance programmes provide mechanisms for coping with shocks; they include contributory pensions, insurance, and federal or private-but-subsidized, fee-based services. Social protection systems are multidimensional and complex, often encompassing several programmes or sectors. They are used to address poverty, both chronic and transitory, and to reduce vulnerability.

The countries of Latin America and the Caribbean have experienced two major waves of reform in their social protection systems. During the early 1990s, several reforms were made to social insurance programmes, particularly the old-age and disability pension systems. These programmes, all heavily dependent on the government's capacity to finance them, had been developed in the 1920s and reformed mid-century, following Bismarck's and then Beveridge's ideas on the welfare state.

The need for adjustment emerged in the aftermath of the 1980s debt crisis. Large deficits generated by social funds fostered widespread adoption of neoliberal economic policies across the region. Several countries changed their defined benefits schemes to defined-contribution and fully-funded systems, while others made parametrical changes to manage the fiscal pressure. In 1981 Chile became the first country to replace the regional pay-as-you-go (PAYG) system with private savings accounts for retirement. Several countries followed suit in the 1990s, some embracing Chile's system (the Dominican Republic, El Salvador, Mexico and the Plurinational State of Bolivia) while others (Argentina, Colombia, Costa Rica, Peru and Uruguay) mixed private accounts with defined-benefit PAYG systems (see Barrientos 2011 and Mesa-Lago 2008 for further details).

The second wave of regional social protection reforms occurred in the early years of the 2000 decade and focused on social assistance. Most of the region's countries expanded their social-assistance programmes by recognizing different life cycle needs and introducing non-contributory income transfers targeting the poor and vulnerable. Several countries extended the non-contributory pension to reduce old-age poverty (such as Panama's Special Cash Transfers Programme for Older Adults (120 at 65), Trinidad and Tobago's Senior Citizens' Pension, Chile's Basic Solidarity Pension, and Brazil's Continuous Benefit Programme (BPC). Over the last 15 years, 18 Latin American and Caribbean countries have introduced similar reforms, increasing elderly income protection by expanding coverage beyond formal-sector workers (Rofman, Apella and Vezza, 2015).

In addition, while recognizing the importance of childhood development and dependency on others (parents or caretakers), several systems also designed programmes to promote and protect development. For example, in 2009, the Chile Crece Contigo [Chile grows with you] programme allowed mothers access to health care during pregnancy and offered children regular check-ups from birth until they entered school. Coverage was later extended through to the completion of primary 
education. The education and health ministries were also involved to provide a comprehensive set of childhood development programmes. Similarly, Peru's national development and social inclusion strategy, "Inclusion for Growth", focused on five different areas of child and adolescent development, aiming to reduce early childhood malnutrition, improve physical and emotional development, and foster the capabilities of older children. Bolivia, Colombia, and the Bolivarian Republic of Venezuela have all developed similar programmes.

Table 1 lists several non-contributory pension programmes and their characteristics. Most programmes were implemented independently from the existing contributory pension system, targeting individuals who were previously excluded; in other cases, the newly established non-contributory systems became part of the previous scheme (for example in Brazil, Chile, and Uruguay).

Table 1

Latin America and the Caribbean (selected countries): non-contributory pension programmes, by beneficiary population and integration with contributory system

\begin{tabular}{|c|c|c|c|}
\hline Country & Programme & Beneficiary population & $\begin{array}{l}\text { Integration with } \\
\text { contributory system }\end{array}$ \\
\hline Argentina & Pension Inclusion Programme & Targeted to achieve universality & Independent \\
\hline $\begin{array}{l}\text { Bolivia (Plurinational } \\
\text { State of) }\end{array}$ & Renta Dignidad & Universal & Independent \\
\hline Brazil & $\begin{array}{l}\text { Rural Pension } \\
\text { Continuous benefit programme }\end{array}$ & $\begin{array}{l}\text { Targeted to achieve universality } \\
\text { Targeted to achieve universality }\end{array}$ & $\begin{array}{l}\text { Integrated } \\
\text { Integrated }\end{array}$ \\
\hline Chile & Basic Solidarity Pension & Targeted to achieve universality & Integrated \\
\hline Colombia & Colombia Mayor & Targeted & Independent \\
\hline Costa Rica & Non-contributory scheme for basic pensions & Targeted & Independent \\
\hline Ecuador & Human Development Grant & Targeted & Independent \\
\hline El Salvador & Universal Basic Pension & Targeted & Independent \\
\hline Mexico & "70 and over" & Targeted to achieve universality & Independent \\
\hline Panama & $\begin{array}{l}\text { Special Cash Transfers Programme } \\
\text { for Older Adults (120 at 65) }\end{array}$ & Targeted to achieve universality & Independent \\
\hline Paraguay & Maintenance for Older Persons & Targeted & Independent \\
\hline Peru & $\begin{array}{l}\text { "Pension 65" National Solidarity } \\
\text { Assistance Programme }\end{array}$ & Targeted & Independent \\
\hline Uruguay & $\begin{array}{l}\text { Contributory system relaxation/ } \\
\text { Elderly Pension Reform }\end{array}$ & Targeted to achieve universality & Integrated \\
\hline Trinidad and Tobago & Senior Citizens' Pension & Universal & Integrated \\
\hline
\end{tabular}

Source: Prepared by the author, on the basis of R. Rofman, I. Apella and E. Vezza (eds.), Beyond Contributory Pensions: Fourteen Experiences with Coverage Expansion in Latin America, Washington, D.C., World Bank, 2015; and Economic Commission for Latin America and the Caribbean, Non-contributory Social Protection Programmes Database - Latin America and the Caribbean, 2016 [online] https://dds.cepal.org/bpsnc/home.

This wave of reforms also introduced conditional cash transfer (CCT) programmes. Following Mexico's pioneering CCT Progresa (later known as Oportunidades, and now Prospera), which was designed and implemented in the late 1990s, all other Latin America and Caribbean countries have incorporated these types of programmes into their social assistance schemes. Although such programmes are non-contributory, the beneficiaries have to fulfil conditions to obtain the benefits. Conditional cash transfer programmes seek to change behaviour by requiring their beneficiaries to make use of health, nutrition, and education services, and by linking human capital accumulation to income transfers. This model of social assistance helps recipients in the short term by providing direct income support to poor and vulnerable households and by promoting human capital accumulation. In the long term it also promotes development and reduces dependency. 
Table 2 lists the CCT programmes implemented in the region, most of which focus on school attendance and health check-ups, targeting women and children. Nonetheless, the programmes vary in their conditions, complexity, and breadth. Each country has tailored its programmes to its specific political and institutional context, with differences in terms of benefits, delivery mechanisms, geographic and demographic coverage, institutional linkages, and budgetary commitment (Cecchini and Atuesta, 2017). The latest data show that coverage varies significantly between countries. In some cases, the programmes serve more than a quarter of the population (for example, those of Brazil, the Dominican Republic, Ecuador and Mexico) whereas others (such as those of Belize, Chile, Costa Rica, and Haiti) cover less than $5 \%$. Low coverage could actually be a sign of success for programmes targeted on the extreme poor, as in the case of Chile or Costa Rica; but, in other cases (Belize or Haiti) it is a sign of institutional or implementation difficulties. Regionwide, CCT coverage increased from fewer than 300,000 households in 1997 to 29.8 million in 2015 (17.5\% of all households in the region). However, the data show a decline in participation from 2014 onward -a troublesome trend as it coincides with rising poverty rates across Latin America and the Caribbean (Cecchini and Atuesta, 2017).

Table 2

Latin America and the Caribbean (selected countries): conditional cash transfer programmes

\begin{tabular}{|c|c|c|c|}
\hline Country & Programme & Conditionality & $\begin{array}{c}\text { Coverage } \\
\text { (percentages) }\end{array}$ \\
\hline \multirow[t]{4}{*}{ Argentina } & Families for Social Inclusion (FIS). (2005-2010) & $\mathrm{E}, \mathrm{H}$ and $\mathrm{S}$ & 7.47 \\
\hline & Universal Child Allowance (AUH) (AUH) (2009-) & $\mathrm{E}, \mathrm{H}$ and $\mathrm{S}$ & 8.04 \\
\hline & Porteña.citizenship programme (2005-) & $E, H$, and Id & 0.38 \\
\hline & Unemployed Heads of Household Plan (2002-2005) & $\mathrm{E}, \mathrm{H}$ and $\mathrm{T}$ & 5.56 \\
\hline Belize & Building Opportunities for Our Social Transformation, BO0ST (2011-) & $\mathrm{E}$ and $\mathrm{H}$ & 2.65 \\
\hline \multirow{2}{*}{$\begin{array}{l}\text { Bolivia (Plurinational } \\
\text { State of) }\end{array}$} & Juancito Pinto Grant (2006-) & $\mathrm{E}$ & 20.74 \\
\hline & Juana Azurduy Mother-and-Child Grant (2009-) & $\mathrm{E}$ and $\mathrm{H}$ & 2.19 \\
\hline \multirow[t]{5}{*}{ Brazil } & Bolsa Escola (2001-2003) & $E$ & 0.00 \\
\hline & Bolsa Família (2003-) & $\mathrm{E}, \mathrm{H}$ and $\mathrm{S}$ & 26.57 \\
\hline & Bolsa Alimentação (2001-2003) & $\mathrm{H}$ & 0.00 \\
\hline & Child Labour Eradication Programme (PETI) (1997-) & $E$ and $S$ & 0.43 \\
\hline & Bolsa Verde (2011-) & NRS & 0.14 \\
\hline \multirow[t]{2}{*}{ Chile } & Solidarity Chile (2002-2012) & $\mathrm{E}$ and $\mathrm{H}$ & 12.36 \\
\hline & Ethical Family Income (2012-) & $\mathrm{E}, \mathrm{H}$ and $\mathrm{L}$ & 4.08 \\
\hline \multirow[t]{4}{*}{ Colombia } & Families in Action & $\mathrm{E}, \mathrm{H}$ and $\mathrm{T}$ & 9.21 \\
\hline & Income for Social Prosperity & $\mathrm{E}$ and $\mathrm{H}$ & - \\
\hline & Unidos Network & E and $S$ & 9.65 \\
\hline & Conditional Subsidies for School Attendance (Bogotá) & E & 0.10 \\
\hline \multirow[t]{2}{*}{ Costa Rica } & Superémonos (2000-2002) & E & - \\
\hline & Avancemos (2006-) & $\mathrm{E}$ and $\mathrm{H}$ & 3.15 \\
\hline \multirow{2}{*}{ Dominican Republic } & Solidarity (2005-2012) & $\mathrm{E}$ and $\mathrm{H}$ & 29.37 \\
\hline & Progressing with Solidarity (2012-) & $\mathrm{E}$ and $\mathrm{H}$ & 31.33 \\
\hline \multirow[t]{2}{*}{ Ecuador } & Human Development Grant (BDH) (2003-) & $\mathrm{E}$ and $\mathrm{H}$ & 32.60 \\
\hline & Zero Malnutrition (2011-) & $\mathrm{E}, \mathrm{H}$ and $\mathrm{S}$ & - \\
\hline El Salvador & $\begin{array}{l}\text { Programme of Support for Solidarity in Communities } \\
\text { in El Salvador (PACSES) (2005-) }\end{array}$ & $\mathrm{E}, \mathrm{H}, \mathrm{T}$ and $\mathrm{S}$ & 8.58 \\
\hline \multirow[t]{3}{*}{ Guatemala } & Mi Familia Progresa (MIFAPR0). (2008-2011) & $\mathrm{E}$ and $\mathrm{H}$ & - \\
\hline & My Secure Grant. (2012-) & $\mathrm{E}$ and $\mathrm{H}$ & 13.02 \\
\hline & Protection and development of working childhood and adolescence (2007-2008) & $\mathrm{E}$ & - \\
\hline Haiti & Ti Manman Cheri (2012) & E & 4.40 \\
\hline \multirow[t]{4}{*}{ Honduras } & Family Allowance Programme (PRAF) and PRAF I. (1990-2009) & $\mathrm{E}$ and $\mathrm{H}$ & 8.96 \\
\hline & PRAF/IDB Phase II. (1998-2005) & $\mathrm{E}, \mathrm{H}$ and $\mathrm{S}$ & - \\
\hline & PRAF/ IDB Phase III. (2006-2009) & $\mathrm{E}$ and $\mathrm{H}$ & - \\
\hline & Bono 10000 programme for Education, Health and Nutrition. (2010-) & E and $\mathrm{H}$ & 19.97 \\
\hline Jamaica & Programme of Advancement Through Health and Education (PATH (PATH) & $\mathrm{E}$ and $\mathrm{H}$ & 13.51 \\
\hline
\end{tabular}


Table 2 (concluded)

\begin{tabular}{llcr}
\hline \multirow{2}{*}{ Country } & Programme & Conditionality & $\begin{array}{c}\text { Coverage } \\
\text { (percentages) }\end{array}$ \\
\hline \multirow{2}{*}{ Mexico } & Opportunities Human Development Programme, formerly Progresa.(1997-2014) & E and H & 24.90 \\
\cline { 2 - 4 } & Prospera (social inclusion programme. (2014-) & E and H & 24.65 \\
\hline \multirow{2}{*}{ Nicaragua } & Crisis support programme & E, H and T & - \\
\cline { 2 - 4 } Panama & Social Protection Network & E, H and T & - \\
\hline \multirow{2}{*}{ Paraguay } & Grant for Food Purchase & E, H and T & 7.62 \\
\hline Peru & Abrazos programme & E, H and T & 1.18 \\
\hline Trinidad and Tobago & Targeted Conditional Cash Transfer Program (TCCTP) & E and S & 0.11 \\
\hline Uruguay & Family allowances & S & 8.63 \\
\cline { 2 - 4 } & National Social Emergency Response Plan (PANES) & E and H & 10.67 \\
\hline
\end{tabular}

Source:Economic Commission for Latin America and the Caribbean (ECLAC), Non-contributory Social Protection Programmes Database - Latin America and the Caribbean, 2016 [online] https://dds.cepal.org/bpsnc/home.

Note: $\quad E$ stands for education, $\mathrm{H}$ for health, $\mathrm{L}$ for labour, $\mathrm{S}$ for social, Id for identification, $\mathrm{T}$ for training, NRS for natural resource and sustainability and CA for community activities.

As shown in table 2, most CCT programmes make their cash transfers conditional on households making investments in education and health. The educational conditions include school enrolment and attendance, ${ }^{10}$ and in some cases specific performance measures (for example in Chile, Colombia, and Guatemala). Health conditions include periodic check-ups (mostly targeting newborns and children), vaccinations for young children, perinatal care for mothers, and attendance at health information meetings. Some CCT programmes have grown in complexity beyond health and education, adding conditions to address other dimensions of poverty and vulnerability.

In line with the Sustainable Development Goals, countries are also recognizing the linkages between poverty and the environment. Nonetheless, only one CCT encourages ecosystem conservation while simultaneously improving living conditions for the poor. Built on Brazil's CCT Bolsa Familia family allowance programme, the Bolsa Verde programme encourages beneficiary families living in conservation priority areas to adopt sustainable practices by providing cash transfers as incentives. This innovative programme fosters conservation, supports improvements in living standards, increases income for those undertaking conservation activities, and encourages participation in environmental, social, technical, and professional training. Activity is monitored via satellite and periodic visits. As more than $50 \%$ of Brazil's extremely poor live in rural areas, this programme represents an important step towards recognizing and compensating those traditional communities and family farmers for the environmental services they provide.

In 2016, the Dominican Republic designed and implemented the Climate Change Adaptation and Vulnerability Index (IVACC). This index contains information on 2.5 million households and calculates which areas and households face the greatest risk from the yearly ravages of the hurricane season. This knowledge can help prevent both human and material losses and also inform the design and implementation of remedial actions targeted to the most vulnerable sectors. The index also acts as a crucial targeting tool for various social programmes by adding supplementary information on vulnerability and enabling better understanding of the risk exposure that determines multidimensional poverty. The first index of its kind, IVACC helps target governmental action, avoiding loss of social investment and optimizing social expenditure. It has become the cornerstone of the country's Prevention, Mitigation and Response (PMR) Plan and facilitated overall coordination of its social protection system.

\footnotetext{
${ }^{10}$ School attendance requirements range from $80 \%$ of school days in the Plurinational State of Bolivia to $95 \%$ in Nicaragua. Most countries set the minimum requirement to $85 \%$.
} 
These waves of reform were a product of political change and popular demand, coupled with a robust fiscal position. They largely explain the impressive improvements the region experienced over this period of time. The programmes' expansion came hand-in-hand with increased government spending on social protection. Between 2002 and 2012, per capita government social spending grew at an average annual rate of $7.3 \%$ across Latin American and Caribbean countries, driven by social protection expenditures (UNDP, 2016a).

However, these efforts have not been sufficient. The region still faces major challenges in increasing social protection coverage. On average, the region covers just $56 \%$ of the population above the minimum pensionable age, with many countries falling well below this level (for example, the Dominican Republic, El Salvador, Guatemala, Honduras, Paraguay and others). Access to health services also remains highly unequal and dependent on employment type and geographical location. The large segments of the population who work in the informal sector or are territorially marginalized cannot access social security benefits at all.

Table 3 displays the vast differences that exist between countries in terms of social protection coverage. Countries such as, Chile, Mexico and Peru all have coverage levels above $86 \%$, while coverage in Honduras is just 2.5\%; a large group of countries (Argentina, Belize, Brazil, Colombia and Nicaragua) cover less than half their population. There are also significant gaps in terms of social protection coverage for women and even more so for other vulnerable groups, such as the LGBTI population.

Table 3

Latin America and the Caribbean: social policy coverage, 2015 (Percentages)

\begin{tabular}{|c|c|c|c|}
\hline & $\begin{array}{l}\text { All social protection and } \\
\text { labour market coverage }\end{array}$ & All social assistance coverage & All social insurance coverage \\
\hline \multicolumn{4}{|l|}{ South America } \\
\hline Argentina & 41.1 & 16.3 & 29.0 \\
\hline Bolivia (Plurinational State of) & 76.8 & 75.2 & 8.5 \\
\hline Brazil & 46.4 & 19.5 & 28.3 \\
\hline Chile & 88.4 & 74.2 & 44.6 \\
\hline Colombia & 48.9 & 41.7 & 8.9 \\
\hline Ecuador & 74.0 & 68.0 & 10.7 \\
\hline Paraguay & 52.3 & 47.8 & 6.3 \\
\hline Peru & 89.5 & 86.6 & 12.2 \\
\hline Suriname & - & - & - \\
\hline Uruguay & 79.8 & 59.2 & 36.6 \\
\hline \multicolumn{4}{|l|}{ Central America } \\
\hline Belize & 39.3 & 16.2 & 28.1 \\
\hline Costa Rica & 67.3 & 47.5 & 15.0 \\
\hline El Salvador & 60.2 & 56.2 & 5.5 \\
\hline Guatemala & 64.3 & 61.6 & 3.9 \\
\hline Honduras & 2.5 & 50.9 & 49.2 \\
\hline Mexico & 86.7 & 58.9 & 47.0 \\
\hline Nicaragua & 45.7 & 39.7 & 5.6 \\
\hline Panama & 63.5 & 52.4 & 17.2 \\
\hline \multicolumn{4}{|l|}{ The Caribbean } \\
\hline Dominican Republic & 35.5 & 31.5 & 5.7 \\
\hline Jamaica & 68.8 & 67.3 & 4.3 \\
\hline
\end{tabular}

Source:World Bank, World Development Indicators, 2016 [online database] http://data.worldbank.org/data-catalog/worlddevelopment-indicators.

Note: In cases where data are not available for 2015, the figures shown in the table refer to neighbouring years. 
The large proportion of people who either live in poverty or are economically vulnerable calls for an expansion of social protection systems. Accounting for the economic and social cost of reproduction and dependent care could help make social security a universal human right and bridge the gender gap that the current system has created.

\section{The future of social protection systems and the challenges ahead}

The positive evolution of social protection systems over the past quarter-century in the Latin American and Caribbean region is partly responsible for the success achieved by many countries in reducing poverty and promoting human development. Expanded coverage of non-contributory schemes, coupled with the creation and implementation of both conditional and unconditional cash-transfer programmes, have had a profound impact on millions of lives. However, the new development agenda raises major challenges, putting pressure on social protection systems to develop innovative ways to both retain and expand welfare developments. They call for multidimensional progress at a time when most countries have tight budgets and are under financial constraints. Although Latin America and the Caribbean was able to effectively navigate the aftermath of the 2008 financial crisis, several countries remain at risk of reversing these achievements.

The 2016 Regional Human Development Report for Latin America and the Caribbean highlights the great danger facing the region today. Social protection systems and safety nets play a vital role in ensuring that those at risk of falling back into poverty in the current economic contraction continue to develop and build resilience toward both natural and man-made external shocks (UNDP, 2016a).

To this end, and in response to the 2007-2008 financial crisis, the International Labour Organization (ILO) Social Protection Floor (SPF-I) Initiative proposes that "social protection floors should comprise at least the following basic social-security guarantees: minimum levels of income security during childhood, working age and old age, as well as affordable access to essential health care" [...] "including maternity care, that meets the criteria of availability, accessibility, acceptability and quality" (ILO, 2012).

This initiative calls for a set of nationally defined basic social security guarantees over the citizen life cycle. It guarantees that those in need have access to health care and basic income security, promoting access to necessary goods and services defined at the national level.

The literature also highlights two main drivers calling for stronger social protection systems in Latin America and the Caribbean today. The first is the recognition of poverty as a multidimensional phenomenon. UNDP (2016a) stresses that well-being goes beyond income alone, focusing on combating multidimensional poverty and on "multidimensional progress". In fact, the past decade has seen significant methodological advances in the measurement of multidimensional poverty (Bourguignon and Chakravarty 2003; Bossert, Chakravarty and D'Ambrosio 2009; Alkire and Foster 2011; Chakravarty and D'Ambrosio 2013). The work begun by the Oxford Poverty and Human Development Initiative (OPHI), including the Multidimensional Poverty Index (MPI), is particularly relevant. Initially launched in 2010 by OPHI and UNDP, MPI tracks multidimensional progress in more than 100 countries year-by-year.

Several Latin American and Caribbean countries have implemented (or are designing) their own multidimensional poverty measures (for example, Chile, Colombia, the Dominican Republic, El Salvador, Mexico, Nicaragua and Peru). This new set of measures enhances understanding of poverty and deprivation, by providing evidence on different aspects of well-being that are not captured by income or consumption expenditures. Nonetheless, more information is needed on marginalized groups. 
These new measures and estimations place great pressure on existing government programmes to tackle multiple deprivations. An example is Mexico's Prospera programme. According to 2014 multidimensional poverty measurements in Mexico, 55.3 million (or 42\%) of its people live without access to basic social rights (CONEVAL 2015). This index revealed that most deprivation stemmed from a lack of access to social security, food, and health services. Given this diagnostic, the National Social Development Programme (2014-2018) established that cash transfers should be combined with other policies to build opportunity and enhance capacity to combat poverty in Mexico.

The new approach led Mexico's CCT Progresa programme to evolve into the Prospera social inclusion system. The new programme aimed to strengthen the implementation of social rights and capacity-building, to break the intergenerational cycle of poverty. To achieve this goal, Prospera provides beneficiaries with the following: direct monetary support to improve their quality and quantity of food; access to quality health services; improved education access and scholarships to encourage achievement; and increased access to information on financial literacy, employment training, and more.

The second force for stronger social protection systems is increased exposure to risk and vulnerability to poverty. As noted above, most people who have escaped poverty still live on the edge; any idiosyncratic or aggregate shock could push them back into deprivation. Moreover, the recent frequency and severity of natural disasters such as hurricanes, volcanic eruptions, and earthquakes have impacted millions of lives. For example, the 7.0-magnitude earthquake that struck Haiti in January 2010 took an enormous toll; and high poverty levels coupled with the lack of a strong social protection network has prevented the country from making a rapid recovery. As Haiti continues to improve its infrastructure, it also needs to work toward constructing stronger and more resilient systems.

The fact remains that, while there are several positive examples of innovative progress, the region's existing social protection systems have severe limitations and face major challenges. Further social policy innovation is needed to address these issues and promote a more sustainable and inclusive development process. The main challenges are highlighted below.

\section{Poverty, vulnerability, and excluded groups}

According to UNDP (2016b), over half of the population of Latin America and the Caribbean is either poor or vulnerable to poverty, especially in view of the region's frequent environmental and natural shocks. Most social programmes target the poor, but they do not include those at risk of falling into poverty as beneficiaries; once people leave income poverty, they become ineligible for social assistance, thereby creating a substantial protection gap. There is an urgent need to expand social safety-net programmes to reduce vulnerability and build resistance.

At the same time, vulnerability and exclusion from the social protection system is a function of labour market characteristics and the type of employment. Much of the region's population remains excluded from social protection because of their type of employment; while wage-earning and formal workers are covered by pension and health systems, informal and non-wage-earning workers are not. Expanding access to physical and financial assets, improving care systems, and developing skills could lead to better coping mechanisms and higher levels of protection against shocks for all. Evidence shows that strong social protection systems help people both escape income poverty and avoid falling back into it; for example, increased pension coverage in Chile and Peru seems to be linked to a higher probability of households escaping income poverty (UNDP 2016a).

Several important groups of the population are also excluded from existing social protection systems as a result of flawed design and targeting mechanisms. The need for expansion and reform are justified not only by the expanding vulnerable population, but also as a means to include those who historically have been excluded from the development process. 
Over the past two decades, women's labour market participation has increased significantly, and the gender wage gap has narrowed. However, women still experience institutional and cultural challenges and discrimination, and they earn less than men for the same jobs. The more precarious and less formal nature of their work also makes them more vulnerable. Even when they do manage to enter the formal labour force, they are disproportionately excluded from full-time work because they bear the majority of household and child-related responsibilities. The path toward identifying the existing gender gaps and helping to close them starts by identifying the economic and social costs of reproduction and dependent care. The establishment of a universal social security system that recognizes this, and does not make transfers conditional on labour market participation, will be crucial.

Another important segment of the population, the indigenous community, has also been excluded from the development process and suffered limited access to social protection programmes. They are considered highly vulnerable given their lifestyle and the high level of discrimination they face. As noted earlier, having an indigenous or Afrodescendent ethnic or racial background is associated with a lower probability of escaping poverty; and social protection systems have failed them due to distance or a lack of consistency between government policy and cultural practices.

For example, social protection coverage for indigenous people is extremely low in the Plurinational State of Bolivia, although over $40 \%$ of the country self-identifies as indigenous. ${ }^{11} \mathrm{~A}$ recent study found that much of this exclusion reflects the limited labour market opportunities available to this group (Monterrey Arce, 2013). Additionally, most indigenous people live in rural areas and work the land for subsistence, which places them at risk of experiencing large and damaging natural shocks. The lack of coverage for indigenous people is coupled with a higher incidence of disease and less access to public vaccination programmes (Monterrey Arce, 2013), as well as lower levels of institutional childbirth which increases the risk of maternal mortality. Similar gaps exist in the education indicators, including literacy levels, years of schooling, and attendance.

Similarly, $21.5 \%$ of Panama's population have indigenous and African roots. ${ }^{12}$ These groups have less access to education, training services, and overall opportunities, which results in higher poverty and vulnerability levels. Panama has undertaken several initiatives to improve their social protection coverage, such as simplifying registration systems, designing and implementing multicultural resources for educational and health facilities, and improving infrastructure in remote areas - measures that have been successful in promoting poverty-reduction and human-capital accumulation.

Mexico's Prospera programme has also evolved to target the country's indigenous population. When these groups displayed a low take-up rate and difficulties accessing services, the 2014-2018 Indigenous Plan produced communications materials on health and educational resources in several languages, benefiting the Maya, Tzotzil, Tarahumara, Tepehuanos, Mazahuas, Tlapanecos/Mephaa, Otomís, Huicholes, Coras, Mixteca, and Náhuatl communities. Future goals include producing materials in additional languages. The plan also hired programme staff who speak indigenous languages to gather information on households, thereby enabling the programme to provide personalized guidance and support to beneficiaries.

In the case of groups such as LGBTI that re subject to discrimination, there are no regional studies providing information on their conditions of life. There are also few examples of positive actions to promote their inclusion in social protection systems.

Tailoring social protection systems to the needs of the historically excluded could profoundly impact the lives of millions of people across the region. The question remains: How can governments and citizens design and implement new systems that reach the excluded (for example "the last mile",

\footnotetext{
112012 census data.

122012 census data.
} 
the poorest, most vulnerable and those furthest behind specified in the 2030 Agenda)? Understanding cultural differences and expanding social services to remote areas could be the best combination of actions to promote inclusive growth and equality, while preserving the value of ancient cultures.

\section{Life cycle challenges: tailoring protection to encompass children, youth, the working-age population and the elderly}

Under the new development paradigm that demands multidimensional progress and protection of previous achievements, social protection systems must be reformed to cover citizens throughout their life cycle. These systems must become a continuum of protection, with different programmes to cope with the risks people face at different stages of their lives. Programmes should be designed to cover early childhood development, school-aged children, youth, working-aged adults, and the elderly. Tackling life cycle vulnerabilities prevents people from accumulating risk as they proceed through life; for example, early-childhood development will have a lasting impact on citizens' productivity and well-being in older life. Increased protection and capacity development also help diminish the intergenerational transmission of deprivation and poverty.

Latin American and Caribbean countries are in the midst of a demographic transition, characterized by sustained increases in the older-adult dependency ratio. Decreased birth rates and increased life expectancy are putting pressure on social protection systems, especially old-age pensions and health care. According to the United Nations Population Division, the population's median age, old-age dependency ratio, and life expectancy at birth are all projected to rise significantly in the coming decades (United Nations, 2019) People of working age will face a major shock in the future, as they become fully responsible for both children and elderly dependents, unless countries implement a robust system to bear some of the burden.

Social protection programmes must consider the conditions of each household in terms of its composition and the specific risks it faces. The need for this type of tailoring generates significant information challenges; better data and information systems need to be developed in tandem with reforms.

In the early stages of life, when dependency is high and interventions have long-lasting effects, systems should include programmes focused on nutrition, health, education, and care. For young people starting their working life, programmes should enhance and guarantee access to jobs and opportunities that foster independence, while also supporting reproductive life. In the case of adults, social protection systems should focus on promoting and protecting jobs and generating income, while also equipping citizens with appropriate mechanisms for coping with both idiosyncratic and aggregate shocks. Senior-citizen programmes should focus on income protection and ensuring access to health and care services, in conjunction with contributory and non-contributory pension systems.

In short, public interventions need to be better coordinated, and efforts made to expand the coverage of specific programmes aligned with the different priorities, needs, and risks citizens face throughout their lives.

\section{Combining and articulating programmes and sectors}

Multidimensional problems need both multisectoral and intersectoral responses - a systematic approach to protect citizens against poverty and risk. Across Latin America and the Caribbean, social protection systems have evolved without a master plan in mind; programmes and institutions have proliferated with no clear mandate regarding benefits and beneficiaries, particularly in the case of health systems (Ribe, 
Robalino and Walker 2012). Fragmented systems constrain labour mobility and reduce productivity; and the lack of coordination between programmes makes it difficult to pool risks or take advantage of economies of scale, thereby raising administrative and delivery costs.

Reform of the social protection system should ensure programme and subsystem coordination by exploiting potential synergies between different interventions, reducing duplication and overall effort. Creating a "one-stop shop" for all social programmes would enhance overall efficiency, increase coverage, and improve responsiveness to shocks. The Chile Solidario programme is a good example of an effort to coordinate programmes and extend beneficiary reach; other countries could adopt a similar approach.

One element that could facilitate coordination is the development of a unique beneficiary information system that can guarantee life cycle needs are identified and met in all areas relevant to sustainable development. Incorporating additional dimensions such as ecosystem services, addressing climate resilience and helping citizens cope better with natural disasters into system design also require both coordination and better information sources. The Dominican Republic's IVACC is an example of success.

Single beneficiary registries enable more efficient targeting, by reducing the cost of data collection and management, and minimizing exclusion and inclusion errors. For example, Chile has moved to a new system to identify social programme beneficiaries. The Social Household Registry, which was launched in early 2016, combines information from its former system with administrative data obtained from Chile's unemployment system, social security institute, and other ministries to calculate a household's socioeconomic status - adjusted for the number of dependents - and eligibility for various benefits.

The combination of high levels of vulnerability with unstable labour markets and natural disasters, and the need to foster sustainable development, call for much higher levels of coordination in programme design. Coordinating interventions across different ministries, sectors, and tiers of government is difficult, but not impossible.

\section{Fiscal restrictions and universal programmes vs. targeting}

Earlier waves of social assistance reform occurred during an economic boom period. Now that fiscal space is more exiguous, innovative ways are needed to deal with social protection that both address vulnerabilities and consider the financial restrictions that countries are facing. Thus, another main challenge is how to improve social protection within a fiscal responsibility framework. The new generation of reforms, based on social rights, must tackle design and coordination issues while improving the fiscal capacity to sustain them. This demands not just resources, but a change of mindset. Moving from programmes targeted on specific groups to universal programmes is not easy, especially considering resource scarcity and competing needs. When fiscal resources are limited, decisions on social spending and the role of the State rest with the people. Setting priorities through bottom-up democratic discussion is necessary to legitimize a strong social protection system.

A new fiscal covenant is needed to achieve these results, especially considering the new regional economic conditions. The tax structure should be changed to increase government revenue from direct taxation, as opposed to the indirect and regressive taxation systems currently in place (for example value-added or sales taxes) - which often cancel out the benefits of social transfers altogether (UNDP 2016a) - to meet the challenges of the 2030 Agenda.

The need for social protection resources also represents an opportunity to revise and reform the existing tax systems. New social contracts and political agreements are needed to increase tax revenues while maintaining incentives for economic growth and private sector development. Some 
countries need to reform the administration of their tax system, decreasing the number of deductions and exemptions and closing loopholes; while others should raise tax rates or broaden the tax base to ensure revenue that covers the growing demand for non-contributory benefits.

Each country needs to tailor tax reform to its specific circumstances, strengths, and weaknesses, and reach a lasting social consensus on the funding needed to implement stronger and broader social protection systems.

\section{Technological changes and labour market}

There has been a highly polarizing discussion around technological change and its effects on the labour market. One view sees innovation as an imminent threat that will change or replace most jobs by introducing artificial intelligence and automation. Few countries are ready to confront such rapid and disruptive change; and technological progress and the associated increase in skill premium have contributed to inequality in both advanced and emerging countries (Dabla-Norris and others 2015). Another view highlights the benefits that technological change can bring, as productivity and quality improvements can offer an opportunity to make a positive impact on living standards.

Based on case studies of five Asian countries, Chang and Huynh (2016) find that the sectors most likely to be automated are hospitality, wholesale and retail commerce, construction and manufacturing; in contrast, automation is less likely in education and training, health care and social work. The study implies that the risk of automation is greater in industries that involve the performance of routine and codifiable tasks; and it is lower in those requiring abstract, intuitive, or creative problem-solving ones. The authors also show that women and the less educated are more likely to have jobs at high risk of automation, thus leaving them highly vulnerable. This is especially true in Latin America and the Caribbean, where self-employment, informal work, and jobs in low-skill and low-wage industries can marginalize workers and discourage technological growth.

Technological change is certain disrupt existing systems and policies. Social programmes and public policy must incorporate capacity-building programmes in order to keep abreast of progress and cope with the impending changes. Catering to low-skill workers and women will be particularly important (Chang, Rynhart and Huyn 2016).

\section{Conclusion and questions for further discussion}

Latin America and the Caribbean is the region with the largest number of countries to have achieved most of the Millennium Development Goal targets. In light of the 2030 Agenda for Sustainable Development for the post-2015 period, countries need to recognize and approach multidimensional poverty reduction in a sustainable way. This requires addressing the gaps that exist in protection by providing specific programmes to the marginalized, vulnerable, and poor.

Social protection systems must expand beyond tackling current deprivations to account for environmental and social risks (including exclusion due to discrimination). Implementing a minimum service floor, extended throughout the citizen's life cycle, can break free from existing poverty traps, and help countries attain higher levels of multidimensional development. This new approach must also protect citizens from idiosyncratic and aggregate shocks faced at different stages of their lives.

Based on social justice principles, SPF-I could raise living standards and safeguard past achievements. The Social Protection Floor includes a broad range of initiatives, including age- and gender-sensitive programmes, allowances for family care, food security support, access to health and sanitation, labour market programmes, and more. 
Over the past two decades, Latin America and the Caribbean has done much to increase social protection coverage. However, more of the same will not be enough to attain the SDG targets or to maintain past development achievements. The new development agenda presents countries with an opportunity to reform their social protection systems and tackle several targets simultaneously. The SDG framework acknowledges the importance of social protection, both in itself and as a vehicle for achieving other goals. ${ }^{13}$ As Latin America and the Caribbean prepares to implement it, governments must consider innovative ways to sustain past achievements and include those who have been excluded.

Several questions remain for discussion: (i) Where should countries begin to change their existing social protection systems? (ii) How can governments and citizens decide which dimensions to consider beyond income poverty? (iii) How can low-income countries afford basic social protection programmes and plan for expansion as they become fiscally stronger? (iv) How can citizens and government officials build coalitions to advance social protection reforms toward universality and a minimum floor? (v) What are the coordination challenges in these countries and their institutional implications? (vii) How can countries narrow the gender gap to keep women out of poverty in all its dimensions?

\section{Bibliography}

Alkire, S. and J. Foster (2011), "Counting and multidimensional poverty measurement", Journal of Public Economics, vol. 95, No. 7-8, August.

Barrientos, A. (2011), "On the distributional implications of social protection reforms in Latin America", WIDER Working Paper, No. 2011/069, Helsinki, World Institute for Development Economics Research (UNU-WIDER).

Bossert, W., S. Chakravarty and C. D'Ambrosio (2009), "Multidimensional poverty and material deprivation", Working Paper Series, No. 2000-129, Society for the Study of Economic Inequality (ECINEQ).

Bourguignon, F. and S. Chakravarty (2003), "The measurement of multidimensional poverty", The Journal of Economic Inequality, vol. 1, April.

Bronfman Horovitz, J. (2014), Essays on vulnerability, poverty and social policies: the case of Chile, Washington, D.C., American University.

Bronfman, J. and Hadad, M. I. (2019), Life versus Mogen: Are the Mapuche People Living a Different Life? Working paper, Universidad Adolfo Ibáñez

Cecchini, S. and B. Atuesta (2017), "Conditional cash transfer programmes in Latin America and the Caribbean: coverage and investment trends", Social Policy series, No. 224 (LC/TS.2017/40), Santiago, Economic Commission for Latin America and the Caribbean (ECLAC).

Chakravarty, S. and C. D'Ambrosio (2013), "A family of unit consistent multidimensional poverty indices", Poverty and Social Exclusion around the Mediterranean Sea, V. Berenger and F. Bresson (eds.), New York, Springer.

Chang, J. H. and P. Huynh (2016), ASEAN in Transformation: The Future of Jobs at Risk of Automation, Geneva, International Labour Organization (ILO).

Chang, J. H., G. Rynhart and P. Huynh (2016), ASEAN in Transformation: How Technology is Changing Jobs and Enterprises, Geneva, International Labour Organization (ILO).

CONEVAL (National Council for the Evaluation of Social Development Policy) (2015), "Multidimensional poverty in Mexico", presentation at the Technical Workshop on Multidimensional Poverty, Brasilia, 25-26 August.

Cruces, G. and others (2010), "Vulnerability to poverty in Latin America: empirical evidence from cross-sectional data and robustness analysis with panel data", Working Paper, No. 170, Chronic Poverty Research Centre (CPRC).

Dabla-Norris, E. and others (2015), "Causes and consequences of income inequality: a global perspective", IMF Staff Discussion Note, No. 15/13, Washington, D.C., International Monetary Fund (IMF).

ECLAC (Economic Commission for Latin America and the Caribbean) (2016), The social inequality matrix in Latin America (LC/G.2690(MDS.1/2)), Santiago.

ECLAC (Economic Commission for Latin America and the Caribbean) and others (2018), "Promoting equality: an interregional perspective", Project Documents (LC/TS.2018/50/Rev.1), Santiago.

${ }^{13}$ See annex table A2 for the complete list of the 17 Sustainable Development Goals. 
Government of Belize/CDB (Caribbean Development Bank) (2010), Country Poverty Assessment Final Report, vol. 1, London, Halcrow Group Limited.

ILO (International Labour Organization) (2012), Social Security for All: Building Social Protection Floors and Comprehensive Social Security Systems, Geneva.

López-Calva, L. and others (2014), "Clases medias y vulnerabilidad a la pobreza: reflexiones desde América Latina”, El Trimestre Económico, vol. 81, No. 322, April-June.

Mesa-Lago, C. (2008), Reassembling Social Security: A Survey of Pensions and Health Care Reforms in Latin America, Oxford, Oxford University Press.

Monterrey Arce, J. (2013), "Social protection systems in Latin America and the Caribbean: Plurinational State of Bolivia", Project Documents (LC/W.553), Santiago, Economic Commission for Latin America and the Caribbean (ECLAC).

Rachid, M. and F. Massenzio (2014), Report on the Economic, Social and Cultural Rights of the Transgender Population of Latin America and the Caribbean, Latin American and Caribbean Network of Transgender People (REDLACTRANS) [online] https://plataformalac.org/wp-content/uploads/2016/05/FSCGD20ENG.pdf.

Ribe, H., D. Robalino and I. Walker (2012), From Right to Reality: Incentives, Labor Markets, and the Challenge of Universal Social Protection in Latin America and the Caribbean, Washington, D.C., World Bank.

Rofman, R., I. Apella and E. Vezza (eds.) (2015), Beyond Contributory Pensions: Fourteen Experiences with Coverage Expansion in Latin America, Washington, D.C., World Bank.

Sears, B. and L. Badgett (2012), "Beyond stereotypes: poverty in the LGBT community", Momentum, No. 4. UNAIDS (Joint United Nations Programme on HIV/AIDS) (2016), Prevention Gap Report, Geneva.

UNDP (United Nations Development Programme) (2016a), Multidimensional progress: well-being beyond income. Regional Human Development Report for Latin America and the Caribbean, New York. (2016b), Human Development Report 2016: Human Development for Everyone, New York. (2016c), Leaving No One Behind: A Social Protection Primer for Practitioners, New York. (2010), Human Development Report 2010. The Real Wealth of Nations: Pathways to Human Development, New York.

United Nations (2019), "Data Query” World Population Prospects, 2019 [online] https://population.un.org/ wpp/DataQuery/. (2015), The Millennium Development Goals Report 2015, New York.

Vargas, L. H. (2015), "Disaster response challenges for social protection systems", Towards universal social protection: Latin American pathways and policy tools, ECLAC Books, No. 136 (LC/G.2644-P), S. Cecchini and others (eds.), Santiago, Economic Commission for Latin America and the Caribbean (ECLAC). 


\section{Annex A1}

Table A1.1

Definitions of "Social Protection" from Agencies and International Organizations

\begin{tabular}{|c|c|c|}
\hline Agency & Definition & Source \\
\hline \multirow[t]{2}{*}{$\begin{array}{l}\text { International Labour } \\
\text { Organization (ILO) }\end{array}$} & $\begin{array}{l}\text { "In this report, reference is made to "social protection" } \\
\text { both as an alternative expression for "social security" } \\
\text { and to denote the protection provided by social } \\
\text { security in case of social risks and needs." }\end{array}$ & \multirow[t]{2}{*}{$\begin{array}{l}\text { IL0, World Social Protection Report 2014/2015: } \\
\text { building economic recovery, inclusive } \\
\text { development and social justice, Geneva, } 2014\end{array}$} \\
\hline & $\begin{array}{l}\text { The notion of social security adopted here covers } \\
\text { all measures providing benefits, whether in cash or } \\
\text { in kind, to secure protection, inter alia, from } \\
\text { - lack of work-related income (or insufficient income) caused } \\
\text { by sickness, disability, maternity, employment injury, } \\
\text { unemployment, old age, or death of a family member } \\
\text { - lack of (affordable) access to health care } \\
\text { - insufficient family support, particularly for } \\
\text { children and adult dependants } \\
\text { - general poverty and social exclusion }\end{array}$ & \\
\hline World Bank & $\begin{array}{l}\text { Systems, policies, and programmes that "help individuals } \\
\text { and societies manage risk and volatility and protect } \\
\text { them from poverty and destitution-through instruments } \\
\text { that improve resilience, equity, and opportunity." }\end{array}$ & $\begin{array}{l}\text { World Bank, Resilience, Equity, and Opportunity: } \\
\text { The World Bank's Social Protection and Labor } \\
\text { Strategy 2012-2022, Washington, D.C., } 2012 .\end{array}$ \\
\hline $\begin{array}{l}\text { United Nations } \\
\text { Children's Fund } \\
\text { (UNICEF) }\end{array}$ & $\begin{array}{l}\text { "The set of public and private policies and programs } \\
\text { aimed at preventing, reducing and eliminating economic } \\
\text { and social vulnerabilities to poverty and deprivation." }\end{array}$ & $\begin{array}{l}\text { UNICEF, Integrated Social Protection Systems: } \\
\text { Enhancing Equity for Children, New York, } 2012 .\end{array}$ \\
\hline $\begin{array}{l}\text { Institute of Development } \\
\text { Studies (IDS) }\end{array}$ & $\begin{array}{l}\text { "...All public and private initiatives that provide income or } \\
\text { consumption transfers to the poor, protect the vulnerable } \\
\text { against livelihood risks, and enhance the social status } \\
\text { and rights of the marginalized; with the overall objective } \\
\text { of reducing the economic and social vulnerability of } \\
\text { poor, vulnerable and marginalized groups." }\end{array}$ & $\begin{array}{l}\text { Devereux, Stephen and Rachel Sabates- } \\
\text { Wheeler, 2004. Transformative Social } \\
\text { Protection. IDS Working Paper } 232 .\end{array}$ \\
\hline Asian Development Bank & $\begin{array}{l}\text { "Set of policies and programs designed to reduce } \\
\text { poverty and vulnerability by promoting efficient labour } \\
\text { markets, diminishing people's exposure to risks, } \\
\text { and enhancing their capacity to protect themselves } \\
\text { against hazards and interruption/loss of income." }\end{array}$ & $\begin{array}{l}\text { AsDB, Social Protection, } 2003 \text { [online] https:// } \\
\text { www.adb.org/sites/default/files/institutional- } \\
\text { document/32100/social protection.pdf. }\end{array}$ \\
\hline European Union & $\begin{array}{l}\text { "...the specific set of public actions to address the vulnerability } \\
\text { of people's life via social insurance, offering protection against } \\
\text { risk and adversity throughout life; via social assistance, } \\
\text { offering payments to support and enable the poor; and via } \\
\text { social inclusion efforts that enhance the capability of the } \\
\text { marginalized to access social insurance and assistance." }\end{array}$ & $\begin{array}{l}\text { Robert Schuman Centre for Advanced Studies, } \\
\text { European Report on Development } 2010 . \\
\text { Social Protection for Inclusive Development: } \\
\text { A New Perspective in EU Co-operation with } \\
\text { Africa, European Union, Brussels, } 2010 .\end{array}$ \\
\hline $\begin{array}{l}\text { Joint United Nations } \\
\text { Programme on HIV/ } \\
\text { AIDS (UNAIDS) }\end{array}$ & $\begin{array}{l}\text { "The objective of 'social protection' is broadly to reduce the } \\
\text { economic and social vulnerability of all people, and to enhance } \\
\text { the social status and rights of poor and marginalized people by } \\
\text { providing social transfers, and ensuring access to basic essential } \\
\text { services and equitable regulation, which can take many forms." }\end{array}$ & $\begin{array}{l}\text { M. Temin, HIV-Sensitive Social Protection: What } \\
\text { Does The Evidence Say?, Joint United Nations } \\
\text { Programme on HIV/AIDS (UNAIDS), Geneva, } 2010 .\end{array}$ \\
\hline
\end{tabular}

Source: United Nations Development Programme (UNDP), Leaving No One Behind: A Social Protection Primer for Practitioners, New York, 2016. 
Table A1.2

List of all Sustainable Development Goals

\begin{tabular}{|c|c|}
\hline \multicolumn{2}{|r|}{17 Sustainable Development Goals } \\
\hline Goal 1 & End poverty in all its forms everywhere \\
\hline Goal 2 & End hunger, achieve food security and improved nutrition and promote sustainable agriculture \\
\hline Goal 3 & Ensure healthy lives and promote well-being for all at all ages \\
\hline Goal 4 & Ensure inclusive and equitable quality education and promote lifelong learning opportunities for all \\
\hline Goal 5 & Achieve gender equality and empower all women and girls \\
\hline Goal 6 & Ensure availability and sustainable management of water and sanitation for all \\
\hline Goal 7 & Ensure access to affordable, reliable, sustainable and modern energy for all \\
\hline Goal 8 & Promote sustained, inclusive and sustainable economic growth, full and productive employment and decent work for all \\
\hline Goal 9 & Build resilient infrastructure, promote inclusive and sustainable industrialization and foster innovation \\
\hline Goal 10 & Reduce inequality within and among countries \\
\hline Goal 11 & Make cities and human settlements inclusive, safe, resilient and sustainable \\
\hline Goal 12 & Ensure sustainable consumption and production patterns \\
\hline Goal 13 & Take urgent action to combat climate change and its impacts \\
\hline Goal 14 & Conserve and sustainably use the oceans, seas and marine resources for sustainable development \\
\hline Goal 15 & $\begin{array}{l}\text { Protect, restore and promote sustainable use of terrestrial ecosystems, sustainably manage forests, } \\
\text { combat desertification, and halt and reverse land degradation and halt biodiversity loss }\end{array}$ \\
\hline Goal 16 & $\begin{array}{l}\text { Promote peaceful and inclusive societies for sustainable development, provide access to justice } \\
\text { for all and build effective, accountable and inclusive institutions at all levels }\end{array}$ \\
\hline Goal 17 & Strengthen the means of implementation and revitalize the global partnership for sustainable development \\
\hline
\end{tabular}

Source: United Nations, Transforming our world: the 2030 Agenda for Sustainable Development (A/RES/70/1), New York, 2015. 
Table A1.3

Latin America and the Caribbean: health-related indicators circa 1990-2000-2015

\begin{tabular}{|c|c|c|c|c|c|c|c|c|c|c|c|c|}
\hline & \multicolumn{3}{|c|}{$\begin{array}{l}\text { Child mortality, under-ones } \\
\text { (per 1,000 live births) }\end{array}$} & \multicolumn{3}{|c|}{$\begin{array}{l}\text { Child mortality in under-fives } \\
\text { (per 1,000 live births) }\end{array}$} & \multicolumn{3}{|c|}{$\begin{array}{c}\text { Maternal mortality } \\
\text { (per 100,000 live births) }\end{array}$} & \multicolumn{3}{|c|}{$\begin{array}{l}\text { Prevalence of } \\
\text { undernourishment } \\
\text { in the population } \\
\text { (percentages) }\end{array}$} \\
\hline & 1990 & 2000 & 2015 & 1990 & 2000 & 2015 & 1990 & 2000 & 2015 & 1990 & 2000 & 2015 \\
\hline \multicolumn{13}{|l|}{ South America } \\
\hline Argentina & 24.4 & 18 & 11.1 & 27.6 & 20.2 & 12.5 & 72 & 60 & 52 & 5 & 5 & 5 \\
\hline $\begin{array}{l}\text { Bolivia (Plurinational } \\
\text { State of) }\end{array}$ & 85.6 & 58.8 & 30.6 & 124.4 & 80.2 & 38.4 & 425 & 334 & 206 & 38 & 34.6 & 15.9 \\
\hline Brazil & 50.9 & 28.1 & 14.6 & 60.8 & 32 & 16.4 & 104 & 66 & 44 & 14.8 & 12.3 & 5 \\
\hline Chile & 16 & 9.2 & 7 & 19.1 & 10.9 & 8.1 & 57 & 31 & 22 & 9 & 5 & 5 \\
\hline Colombia & 28.9 & 21.2 & 13.6 & 35.1 & 25.1 & 15.9 & 118 & 97 & 64 & 14.6 & 9.9 & 8.8 \\
\hline Ecuador & 44.2 & 28.4 & 21.6 & 56.9 & 34.4 & 64 & 185 & 103 & 22.5 & 19.4 & 17.8 & 10.9 \\
\hline Guyana & 46.6 & 37.2 & 32 & 60.4 & 46.7 & 39.4 & 171 & 210 & 229 & 22.8 & 10.4 & 10.6 \\
\hline Paraguay & 37.1 & 27.7 & 17.5 & 46.5 & 33.5 & 20.5 & 150 & 158 & 132 & 19.5 & 13.3 & 10.4 \\
\hline Peru & 56.3 & 29.6 & 13.1 & 79.7 & 38.6 & 16.9 & 251 & 140 & 68 & 31.6 & 21.6 & 7.5 \\
\hline Suriname & 40.7 & 30.2 & 19 & 47.6 & 34.4 & 21.3 & 127 & 259 & 155 & 15.5 & 14.1 & 8.3 \\
\hline Uruguay & 20.3 & 14.6 & 8.7 & 23.1 & 16.8 & 10.1 & 37 & 31 & 15 & 8.6 & 5 & 5 \\
\hline $\begin{array}{l}\text { Venezuela (Bolivarian } \\
\text { Republic of) }\end{array}$ & 24.7 & 18.5 & 12.9 & 29.6 & 21.7 & 14.9 & 94 & 90 & 95 & 14.1 & 16.6 & 5 \\
\hline \multicolumn{13}{|l|}{ Central America } \\
\hline Belize & 32.2 & 21.1 & 14.2 & 39.6 & 25 & 16.5 & 54 & 53 & 28 & 9.7 & 6.5 & 6.2 \\
\hline Costa Rica & 14.3 & 11.2 & 8.5 & 16.9 & 13 & 9.7 & 43 & 38 & 25 & 5.2 & 5.2 & 5 \\
\hline El Salvador & 45.9 & 26.8 & 14.4 & 59.4 & 32.4 & 16.8 & 157 & 84 & 54 & 16.2 & 12.5 & 12.4 \\
\hline Guatemala & 59.8 & 39.9 & 24.3 & 80.9 & 50.6 & 29.1 & 205 & 178 & 88 & 14.9 & 22.1 & 15.6 \\
\hline Honduras & 45.1 & 30.5 & 17.4 & 58.2 & 37.4 & 20.4 & 272 & 133 & 129 & 23 & 19 & 12.3 \\
\hline Mexico & 37.1 & 21.6 & 11.3 & 46.6 & 25.6 & 13.2 & 90 & 77 & 38 & 6.9 & 5 & 5 \\
\hline Nicaragua & 50.9 & 32.6 & 18.8 & 66.9 & 40.3 & 22.1 & 173 & 202 & 150 & 54.4 & 34.8 & 16.6 \\
\hline Panama & 25.7 & 21.9 & 14.6 & 30.9 & 26 & 17 & 102 & 82 & 94 & 26.4 & 27.4 & 10 \\
\hline \multicolumn{13}{|l|}{ The Caribbean } \\
\hline Antigua and Barbuda & 24 & 13.8 & 5.8 & 25.5 & 15.5 & 8.1 & - & - & - & - & - & - \\
\hline Bahamas & 19.7 & 13.2 & 9.9 & 23.5 & 15.7 & 12.1 & 46 & 61 & 80 & - & - & - \\
\hline Barbados & 16 & 14.8 & 12 & 17.9 & 16.3 & 13 & 58 & 48 & 27 & 5 & 5 & 5 \\
\hline Cuba & 10.6 & 6.5 & 6.5 & 13.3 & 8.4 & 8.4 & 58 & 43 & 43 & 5.7 & 5.6 & 5 \\
\hline Dominica & 14.2 & 13.4 & 19.6 & 17.1 & 15.3 & 21.2 & - & - & - & - & - & - \\
\hline Dominican Republic & 46.5 & 33.3 & 25.7 & 60.2 & 41.3 & 30.9 & 198 & 79 & 92 & 34.3 & 30.7 & 12.5 \\
\hline Grenada & 18 & 13.6 & 10.8 & 23.3 & 16 & 11.8 & 41 & 29 & 27 & - & - & - \\
\hline Haiti & 101 & 75 & 52.2 & 145.8 & 104.8 & 69 & 625 & 505 & 359 & 61.1 & 55.2 & 53.4 \\
\hline Jamaica & 25.4 & 19.3 & 13.5 & 30.6 & 22.7 & 15.7 & 79 & 88 & 89 & 10.4 & 7.8 & 8.1 \\
\hline Puerto Rico & - & - & - & - & - & - & 26 & 22 & 14 & - & - & - \\
\hline Saint Kitts and Nevis & 23.1 & 15 & 8.4 & 28.4 & 18.6 & 10.5 & - & - & - & - & - & - \\
\hline Saint Lucia & 18.7 & 15.2 & 12.7 & 22.6 & 17.8 & 14.3 & 45 & 54 & 48 & - & - & - \\
\hline $\begin{array}{l}\text { Saint Vincent and } \\
\text { Grenadines }\end{array}$ & 20.3 & 19.2 & 16.6 & 24.5 & 22.2 & 18.3 & 58 & 74 & 45 & 20.7 & 18.9 & 6.2 \\
\hline Trinidad and Tobago & 26.9 & 25.3 & 18.2 & 30.5 & 28.7 & 20.4 & 90 & 62 & 63 & 12.6 & 13 & 8 \\
\hline
\end{tabular}

Source:World Bank, World Development Indicators, Washington, D.C., 2016 [online database] http://data.worldbank.org/datacatalog/world-development-indicators.

Note: In cases where data are not available for the exact year, the figures shown in the table refer to neighbouring years. Several Caribbean countries do not have data available on poverty rates. 
Table A1.4

Latin America and the Caribbean Education-Related Indicators (Circa 1990, 2000 and2015)

\begin{tabular}{|c|c|c|c|c|c|c|c|c|c|c|c|c|}
\hline & \multicolumn{3}{|c|}{$\begin{array}{c}\text { Enrolment rate } \\
\text { (Primary, female) } \\
\text { (percentage of primary } \\
\text { school age children) }\end{array}$} & \multicolumn{3}{|c|}{$\begin{array}{c}\text { Enrolment rate } \\
\text { (Primary, male) } \\
\text { (percentage of primary } \\
\text { school age children) }\end{array}$} & \multicolumn{3}{|c|}{$\begin{array}{l}\text { Enrolment rate } \\
\text { (Secondary, female) } \\
\text { (percentages) }\end{array}$} & \multicolumn{3}{|c|}{$\begin{array}{l}\text { Enrolment rate } \\
\text { (Secondary, male) } \\
\text { (percentages) }\end{array}$} \\
\hline & 1990 & 2000 & 2015 & 1990 & 2000 & 2015 & 1990 & 2000 & 2015 & 1990 & 2000 & 2015 \\
\hline \multicolumn{13}{|l|}{ South America } \\
\hline Argentina & 96.3 & 98.9 & 98.3 & 96.2 & 99.8 & 99.6 & - & 77.2 & 90.3 & - & 72.0 & 84.4 \\
\hline $\begin{array}{l}\text { Bolivia (Plurinational } \\
\text { State of }\end{array}$ & - & 94.3 & 87.0 & - & 95.2 & 88.4 & - & - & 76.2 & - & - & 75.2 \\
\hline Brazil & - & - & - & - & - & - & - & - & - & - & - & - \\
\hline Chile & - & - & 92.4 & - & - & 92.5 & - & - & 90.3 & - & - & 86.9 \\
\hline Colombia & 72.8 & 94.5 & 92.8 & 63.3 & 94.8 & 93.7 & - & - & 80.4 & - & - & 74.1 \\
\hline Ecuador & - & 95.9 & 95.5 & - & 95.1 & 93.8 & - & 48.6 & 84.0 & - & 47.2 & 81.1 \\
\hline Guyana & - & 88.0 & 79.9 & - & 97.0 & 82.8 & - & 72.7 & 82.6 & - & 73.2 & 82.3 \\
\hline Paraguay & 92.1 & 97.7 & 88.3 & 93.8 & 97.1 & 88.8 & 34.3 & 53.6 & 66.3 & 32.4 & 50.9 & 66.6 \\
\hline Peru & 93.3 & 97.5 & 93.1 & 94.2 & 97.9 & 92.5 & - & 63.9 & 79.4 & - & 66.1 & 77.4 \\
\hline Suriname & - & - & 91.8 & - & - & 91.0 & - & - & 50.0 & - & - & 43.9 \\
\hline Uruguay & 92.5 & 92.6 & - & 91.5 & 91.8 & - & - & - & - & - & - & - \\
\hline $\begin{array}{l}\text { Venezuela (Bolivarian } \\
\text { Republic of) }\end{array}$ & - & 86.2 & 90.6 & - & 85.3 & 90.7 & - & 55.3 & 78.5 & - & 45.8 & 71.2 \\
\hline \multicolumn{13}{|l|}{ Central America } \\
\hline Belize & - & 94.0 & 95.5 & - & 95.6 & 97.6 & - & 60.2 & 71.1 & - & 57.0 & 67.3 \\
\hline Costa Rica & 88.0 & - & 96.1 & 87.5 & - & 96.2 & 38.7 & - & 80.1 & 36.4 & - & 76.2 \\
\hline El Salvador & - & 90.3 & 94.7 & - & 90.9 & 94.6 & - & 47.5 & 70.1 & - & 48.6 & 69.0 \\
\hline Guatemala & - & 80.8 & 86.1 & - & 86.9 & 86.7 & - & 24.3 & 45.4 & - & 26.9 & 48.0 \\
\hline Honduras & 88.7 & 89.0 & 94.2 & 87.6 & 88.1 & 93.9 & - & - & 53.0 & - & - & 45.7 \\
\hline Mexico & - & 96.9 & 96.0 & - & 96.3 & 95.3 & - & 59.6 & 68.8 & - & 57.8 & 66.1 \\
\hline Nicaragua & 69.2 & 82.7 & 98.0 & 65.9 & 80.8 & 95.9 & - & 40.8 & 53.0 & - & 33.5 & 45.1 \\
\hline Panama & 86.8 & 95.0 & 95.5 & 86.4 & 95.4 & 96.3 & - & 61.2 & 80.6 & - & 55.5 & 75.2 \\
\hline \multicolumn{13}{|l|}{ The Caribbean } \\
\hline Antigua and Barbuda & - & - & 83.2 & - & - & 86.7 & - & 66.6 & 81.3 & - & 72.0 & 78.2 \\
\hline Bahamas & 88.9 & 89.9 & 98.62 & 88.2 & 91.6 & 93.21 & 90.4 & 70.4 & 85.68 & 87.9 & 71.2 & 79.74 \\
\hline Barbados & 96.7 & 95.5 & 92.0 & 98.5 & 95.5 & 90.1 & 73.7 & 91.3 & 100.0 & 84.0 & 92.5 & 98.9 \\
\hline Bermuda & - & - & 81.5 & - & - & 85.3 & - & - & 78.6 & - & - & 67.9 \\
\hline Cuba & 92.5 & 96.1 & 93.5 & 92.5 & 97.2 & 92.8 & 72.0 & 82.3 & 91.1 & 67.1 & 80.0 & 87.9 \\
\hline Dominica & - & - & - & - & - & - & - & 89.5 & 81.5 & - & 78.2 & 76.5 \\
\hline Dominican Republic & - & 83.7 & 82.6 & - & 83.2 & 84.5 & - & 44.2 & 69.8 & - & 35.7 & 61.2 \\
\hline Grenada & - & 93.7 & 89.5 & - & 95.1 & 91.5 & - & 91.2 & 80.9 & - & 76.1 & 79.6 \\
\hline Haiti & - & 56.9 & - & - & 57.8 & - & - & - & - & - & - & - \\
\hline Jamaica & 98.4 & 92.1 & - & 98.1 & 92.5 & - & - & 78.5 & 77.5 & - & 76.1 & 69.7 \\
\hline Puerto Rico & - & - & 83.3 & - & - & 80.0 & - & - & 77.2 & - & - & 72.3 \\
\hline Saint Kitts and Nevis & - & 95.7 & 80.2 & - & 93.4 & 77.8 & 80.0 & 98.9 & 84.7 & 78.0 & 92.9 & 81.2 \\
\hline Saint Lucia & 95.9 & 87.1 & - & 98.7 & 91.4 & - & - & 69.5 & 81.2 & - & 54.8 & 80.2 \\
\hline $\begin{array}{l}\text { Saint Vincent and } \\
\text { the Grenadines }\end{array}$ & - & - & 84.8 & - & - & 86.6 & - & 78.4 & 86.5 & - & 57.6 & 83.9 \\
\hline Trinidad and Tobago & 91.9 & 93.8 & 94.8 & 88.2 & 93.9 & 95.7 & 68.0 & 75.2 & - & 65.7 & 70.2 & - \\
\hline
\end{tabular}

Source: World Bank, World Development Indicators, Washington, D.C., 2016 [online database] http://data.worldbank.org/datacatalog/world-development-indicators.

Note: In cases where data are not available for the exact year, the figures shown in the table refer to neighbouring years. Several Caribbean countries do not have data available on poverty rates. 
Table A1.5

Latin America and the Caribbean Access to Water (Circa 1990-2000-2015) (Percentages)

\begin{tabular}{|c|c|c|c|c|c|c|}
\hline & \multicolumn{3}{|c|}{ Water Access - Urban population } & \multicolumn{3}{|c|}{ Water Access - Rural population } \\
\hline & 1990 & 2000 & 2015 & 1990 & 2000 & 2015 \\
\hline \multicolumn{7}{|l|}{ South America } \\
\hline Argentina & 97.5 & 98.1 & 99.0 & 68.8 & 81.3 & 100 \\
\hline Bolivia (Plurinational State of) & 90.5 & 93.1 & 96.7 & 40.4 & 55.1 & 75.6 \\
\hline Brazil & 95.8 & 97.6 & 100 & 67.7 & 75.7 & 87.0 \\
\hline Chile & 98.9 & 99.2 & 99.7 & 48.2 & 67.8 & 93.3 \\
\hline Colombia & 97.5 & 97.2 & 96.8 & 68.8 & 71.0 & 73.8 \\
\hline Ecuador & 83.9 & 87.9 & 93.4 & 61.4 & 67.3 & 75.5 \\
\hline Guyana & 92.6 & 94.5 & 98.2 & 73.6 & 81.8 & 98.3 \\
\hline Paraguay & 84.9 & 91.0 & 100 & 22.7 & 51.6 & 94.9 \\
\hline Peru & 88.0 & 89.4 & 91.4 & 43.9 & 54 & 69.2 \\
\hline Suriname & 97.8 & 97.8 & 98.1 & - & 72.5 & 88.4 \\
\hline Uruguay & 97.8 & 98.5 & 100 & 70.3 & 77.0 & 93.9 \\
\hline Venezuela (Bolivarian Republic of) & 92.6 & 93.6 & 95.0 & 68.4 & 72.5 & 77.9 \\
\hline \multicolumn{7}{|l|}{ Central America } \\
\hline Belize & 87.4 & 92.4 & 98.9 & 59.8 & 78.5 & 100 \\
\hline Costa Rica & 99.2 & 99.4 & 99.6 & 86.5 & 88.8 & 91.9 \\
\hline El Salvador & 90.4 & 93.3 & 97.5 & 50.6 & 65.0 & 86.5 \\
\hline Guatemala & 89.8 & 93.6 & 98.4 & 67.5 & 75.9 & 86.8 \\
\hline Honduras & 92.4 & 94.4 & 97.4 & 59.9 & 69.5 & 83.8 \\
\hline Mexico & 91.5 & 94.1 & 97.2 & 59.4 & 74.4 & 92.1 \\
\hline Nicaragua & 90.6 & 94.4 & 99.3 & 53.0 & 60.1 & 69.4 \\
\hline Panama & 97.8 & 97.8 & 97.7 & 67.5 & 75.9 & 88.6 \\
\hline \multicolumn{7}{|l|}{ The Caribbean } \\
\hline Antigua and Barbuda & 97.4 & 97.7 & 97.9 & 97.4 & 97.7 & 97.9 \\
\hline Bahamas & 96.3 & 96.6 & 98.4 & 96.3 & 96.6 & 98.4 \\
\hline Barbados & 96.1 & 97.6 & 99.7 & 96.1 & 97.6 & 99.7 \\
\hline Bermuda & - & - & - & - & - & - \\
\hline British Virgin Islands & 94.8 & 94.9 & - & 94.8 & 94.9 & - \\
\hline Cayman Islands & 92.3 & 93.3 & 97.4 & - & - & - \\
\hline Cuba & 93.9 & 94.9 & 96.4 & - & 77.3 & 89.8 \\
\hline Dominica & 95.7 & 95.7 & 95.7 & - & 91.8 & - \\
\hline Dominican Republic & 96.7 & 92.2 & 85.4 & 75.8 & 78.2 & 81.9 \\
\hline Grenada & 99.0 & 99 & 99 & 95.3 & 95.3 & 95.3 \\
\hline Haiti & 91.2 & 81.6 & 64.9 & 50.2 & 49.3 & 47.6 \\
\hline Jamaica & 97.9 & 97.7 & 97.5 & 88.5 & 88.9 & 89.4 \\
\hline Puerto Rico & 93.6 & 93.6 & - & 93.6 & 93.6 & - \\
\hline Saint Kitts and Nevis & 98.3 & 98.3 & 98.3 & 98.3 & 98.3 & 98.3 \\
\hline Saint Lucia & 95.4 & 97.1 & 99.5 & 91.3 & 93.1 & 95.6 \\
\hline Saint Vincent and the Grenadines & 88.2 & 93.5 & 95.1 & 88.2 & 93.5 & 95.1 \\
\hline Trinidad and Tobago & 91.6 & 93.3 & 95.0 & 91.6 & 93.3 & 95.0 \\
\hline Turks and Caicos Islands & 87.1 & 87.1 & - & 87.0 & 87.0 & - \\
\hline United States Virgin Islands & 100 & 100 & 100 & 100 & 100 & 100 \\
\hline
\end{tabular}

Source:World Bank, World Development Indicators, Washington, D.C., 2016 [online database] http://data.worldbank.org/datacatalog/world-development-indicators.

Note: In cases where data are not available for the exact year, the figures shown in the table refer to neighbouring years. Several Caribbean countries do not have data available on poverty rates. 
Table A1.6

Latin America and the Caribbean: employment related indicators

(around 1990, 2000 and 2015)

(Percentages)

\begin{tabular}{|c|c|c|c|c|c|c|c|c|c|c|c|c|}
\hline & \multicolumn{3}{|c|}{ Unemployment (Total) } & \multicolumn{3}{|c|}{ Unemployment (Male) } & \multicolumn{3}{|c|}{ Unemployment (Female) } & \multicolumn{3}{|c|}{ Informal employmenta ${ }^{\mathrm{a}}$} \\
\hline & 1990 & 2000 & 2015 & 1990 & 2000 & 2015 & 1990 & 2000 & 2015 & 1990 & 2000 & 2015 \\
\hline \multicolumn{13}{|l|}{ South America } \\
\hline Argentina & 5.8 & 15.0 & 8.2 & 5.4 & 13.7 & 7.1 & 6.4 & 17.1 & 9.8 & 45.0 & 42.0 & 47.1 \\
\hline $\begin{array}{l}\text { Bolivia (Plurinational } \\
\text { State of) }\end{array}$ & 2.9 & 4.8 & 2.7 & 2.4 & 4.0 & 2.2 & 3.8 & 5.9 & 3.3 & - & - & 71.8 \\
\hline Brazil & 6.9 & 9.5 & 6.8 & 5.3 & 7.7 & 5.2 & 9.6 & 12.0 & 8.7 & 41.9 & 46.6 & 36.8 \\
\hline Chile & 8.1 & 9.2 & 6.4 & 7.3 & 8.8 & 5.8 & 10.1 & 10.1 & 7.3 & 33.7 & 33.1 & - \\
\hline Colombia & 13.9 & 16.6 & 10.1 & 11.5 & 13.0 & 7.7 & 19.6 & 22.2 & 13.3 & 50.0 & 60.9 & 63.7 \\
\hline Ecuador & 4.0 & 7.2 & 4.6 & 3.4 & 5.4 & 3.5 & 5.2 & 10.1 & 6.2 & - & 48.1 & - \\
\hline Guyana & 12.0 & 11.5 & 11.1 & 9.4 & 9.8 & 9.6 & 17.4 & 15.1 & 14.0 & - & - & - \\
\hline Paraguay & 6.5 & 7.6 & 4.5 & 5.4 & 6.7 & 3.8 & 8.5 & 9.2 & 5.6 & - & - & 64.4 \\
\hline Peru & 6.0 & 6.4 & 4.2 & 5.5 & 6.1 & 3.7 & 6.9 & 6.8 & 4.8 & - & - & 68.8 \\
\hline Suriname & 10.6 & 14.8 & 5.6 & 8.3 & 11.7 & 3.6 & 14.8 & 20.6 & 8.9 & - & - & - \\
\hline Uruguay & 7.0 & 10.7 & 7.0 & 5.4 & 7.9 & 5.3 & 9.5 & 14.5 & 9.1 & - & 40.3 & - \\
\hline $\begin{array}{l}\text { Venezuela (Bolivarian } \\
\text { Republic of) }\end{array}$ & 9.5 & 13.2 & 8.6 & 8.8 & 12.6 & 8.1 & 10.9 & 14.3 & 9.4 & - & - & - \\
\hline \multicolumn{13}{|l|}{ Central America } \\
\hline Belize & 10.8 & 10.9 & 11.5 & 7.9 & 8.0 & 6.5 & 17.6 & 16.9 & 19.7 & - & - & - \\
\hline Costa Rica & 5.6 & 5.1 & 8.3 & 4.8 & 4.3 & 6.7 & 7.7 & 6.8 & 11.0 & 36.5 & 35.4 & 30.7 \\
\hline El Salvador & 6.5 & 7.0 & 6.2 & 7.9 & 8.6 & 7.4 & 4.0 & 4.5 & 4.4 & - & - & 65.4 \\
\hline Guatemala & 3.2 & 1.4 & 2.9 & 3.2 & 1.2 & 2.8 & 3.3 & 1.8 & 3.0 & - & - & 74.4 \\
\hline Honduras & 4.7 & 3.9 & 3.9 & 4.0 & 3.8 & 3.3 & 6.4 & 4.1 & 5.1 & 47.2 & 60.9 & 73.4 \\
\hline Mexico & 3.0 & 2.5 & 4.9 & 2.5 & 2.1 & 4.9 & 4.2 & 3.2 & 5.0 & - & - & 53.9 \\
\hline Nicaragua & 4.7 & 6.2 & 5.3 & 4.7 & 7.4 & 5.3 & 4.7 & 3.7 & 5.3 & - & 57.0 & - \\
\hline Panama & 16.1 & 13.5 & 4.3 & 12.8 & 11.1 & 3.6 & 22.7 & 17.8 & 5.6 & 33.3 & 32.8 & - \\
\hline \multicolumn{13}{|l|}{ The Caribbean } \\
\hline Bahamas & 12.2 & 7.2 & 15.4 & 12.4 & 5.7 & 15.1 & 12.0 & 8.8 & 15.7 & - & - & - \\
\hline Barbados & 17.1 & 9.3 & 12.0 & 13.5 & 7.3 & 9.9 & 21.1 & 11.6 & 14.3 & - & - & - \\
\hline Bermuda & - & - & - & - & - & - & - & - & - & - & - & - \\
\hline Cuba & 2.3 & 5.4 & 3.3 & 2.1 & 4.9 & 2.9 & 2.7 & 6.4 & 3.9 & - & - & - \\
\hline Dominican Republic & 19.9 & 14.2 & 15.0 & 12.9 & 8.8 & 9.5 & 33.5 & 23.6 & 23.4 & - & - & 51.4 \\
\hline Haiti & 11.4 & 7.4 & 6.8 & 8.6 & 6.4 & 5.9 & 14.8 & 8.5 & 7.8 & - & - & - \\
\hline Jamaica & 15.7 & 15.5 & 13.2 & 9.7 & 10.0 & 9.7 & 22.6 & 22.4 & 17.3 & - & - & - \\
\hline Puerto Rico & 17.1 & 10.3 & 14.3 & 18.9 & 12.1 & 16.1 & 13.7 & 7.5 & 11.9 & - & - & - \\
\hline Trinidad \& Tobago & 18.5 & 12.1 & 4.0 & 15.7 & 10.2 & 3.1 & 22.7 & 15.1 & 5.3 & - & - & - \\
\hline
\end{tabular}

Source:World Bank, World Development Indicators, Washington, D.C., 2016 [online database] http://data.worldbank.org/datacatalog/world-development-indicators.

Note: In cases where data are not available for the exact year, the figures shown in the table refer to neighbouring years. Several Caribbean countries do not have data available on poverty rate.

a Percentages of total non-agricultural employment. 
Table A1.7

Latin America and the Caribbean: human development index (1990, 2000 and 2015)

\begin{tabular}{|c|c|c|c|}
\hline & & evelopm & \\
\hline & 1990 & 2000 & 2015 \\
\hline South America & & & \\
\hline Argentina & 0.71 & 0.76 & 0.84 \\
\hline Bolivia (Plurinational State of) & 0.54 & 0.60 & 0.66 \\
\hline Brazil & 0.61 & 0.68 & 0.76 \\
\hline Chile & 0.69 & 0.75 & 0.83 \\
\hline Colombia & 0.59 & 0.65 & 0.72 \\
\hline Ecuador & 0.65 & 0.70 & 0.77 \\
\hline Guyana & 0.54 & 0.60 & 0.64 \\
\hline Paraguay & 0.58 & 0.62 & 0.68 \\
\hline Peru & 0.61 & 0.68 & 0.73 \\
\hline Suriname & - & - & 0.71 \\
\hline Uruguay & 0.69 & 0.74 & 0.79 \\
\hline Venezuela (Bolivarian Republic of) & 0.64 & 0.67 & 0.76 \\
\hline Central America & & & \\
\hline Belize & 0.64 & 0.68 & 0.72 \\
\hline Costa Rica & 0.65 & 0.70 & 0.77 \\
\hline El Salvador & 0.52 & 0.60 & 0.66 \\
\hline Guatemala & 0.48 & 0.55 & 0.63 \\
\hline Honduras & 0.51 & 0.56 & 0.61 \\
\hline Mexico & 0.65 & 0.70 & 0.76 \\
\hline Nicaragua & 0.50 & 0.57 & 0.63 \\
\hline Panama & 0.66 & 0.68 & 0.78 \\
\hline The Caribbean & & & \\
\hline Antigua and Barbuda & - & - & 0.78 \\
\hline Bahamas & - & 0.78 & 0.79 \\
\hline Barbados & 0.71 & 0.75 & 0.79 \\
\hline Cuba & 0.67 & 0.69 & 0.77 \\
\hline Dominica & - & 0.69 & 0.72 \\
\hline Dominican Republic & 0.57 & 0.65 & 0.72 \\
\hline Grenada & - & - & 0.75 \\
\hline Haiti & 0.42 & 0.44 & 0.48 \\
\hline Jamaica & 0.67 & 0.70 & 0.72 \\
\hline Saint Kitts and Nevis & - & - & 0.75 \\
\hline Saint Lucia & - & - & 0.73 \\
\hline Saint Vincent and the Grenadines & - & - & 0.72 \\
\hline Trinidad and Tobago & 0.67 & 0.72 & 0.77 \\
\hline
\end{tabular}

Source: United Nations Development Programme (UNDP), Human Development Report 2016: Human Development for Everyone, New York, 2016. 
Table A1.8

Latin America and the Caribbean: gender development index, 2014

\begin{tabular}{|c|c|c|c|c|c|c|}
\hline & \multicolumn{2}{|c|}{ Gender development index (GDI) } & \multirow{2}{*}{\multicolumn{2}{|c|}{$\frac{\text { Human development index (HDI) }}{\text { Value }}$}} & \multicolumn{2}{|c|}{ Gender inequality index } \\
\hline & \multirow{2}{*}{ Value } & \multirow{2}{*}{ GDI group } & & & \multirow{2}{*}{ Value } & \multirow{2}{*}{ Rank } \\
\hline & & & Female & Male & & \\
\hline & 2014 & 2014 & 2014 & 2014 & 2014 & 2014 \\
\hline \multicolumn{7}{|l|}{ South America } \\
\hline Argentina & 0.982 & 1 & 0.819 & 0.834 & 0.376 & 75 \\
\hline Bolivia (Plurinational State of) & 0.931 & 3 & 0.637 & 0.684 & 0.444 & 94 \\
\hline Brazil & 0.997 & 1 & 0.752 & 0.754 & 0.457 & 97 \\
\hline Chile & 0.967 & 2 & 0.815 & 0.843 & 0.338 & 65 \\
\hline Colombia & 0.997 & 1 & 0.719 & 0.721 & 0.429 & 92 \\
\hline Ecuador & 0.980 & 1 & 0.722 & 0.737 & 0.407 & 83 \\
\hline Guyana & 0.984 & 1 & 0.626 & 0.636 & 0.515 & 114 \\
\hline Paraguay & 0.956 & 2 & 0.662 & 0.692 & 0.472 & 101 \\
\hline Peru & 0.947 & 3 & 0.712 & 0.752 & 0.406 & 82 \\
\hline Suriname & 0.975 & 1 & 0.702 & 0.720 & 0.463 & 100 \\
\hline Uruguay & 1.018 & 1 & 0.797 & 0.783 & 0.313 & 61 \\
\hline Venezuela (Bolivarian Republic of) & 1.030 & 2 & 0.772 & 0.749 & 0.476 & 103 \\
\hline \multicolumn{7}{|l|}{ Central America } \\
\hline Belize & 0.958 & 2 & 0.696 & 0.727 & 0.426 & 90 \\
\hline Costa Rica & 0.974 & 2 & 0.753 & 0.774 & 0.349 & 66 \\
\hline El Salvador & 0.965 & 2 & 0.652 & 0.676 & 0.427 & 91 \\
\hline Guatemala & 0.949 & 3 & 0.608 & 0.641 & 0.533 & 119 \\
\hline Honduras & 0.944 & 3 & 0.583 & 0.618 & 0.480 & 106 \\
\hline Mexico & 0.943 & 3 & 0.731 & 0.775 & 0.373 & 74 \\
\hline Nicaragua & 0.960 & 2 & 0.615 & 0.640 & 0.449 & 95 \\
\hline Panama & 0.996 & 1 & 0.776 & 0.779 & 0.454 & 96 \\
\hline \multicolumn{7}{|l|}{ The Caribbean } \\
\hline Antigua and Barbuda & - & - & - & - & - & - \\
\hline Bahamas & - & - & - & - & 0.298 & 58 \\
\hline Barbados & 1.018 & 1 & 0.791 & 0.777 & 0.357 & 69 \\
\hline \multicolumn{7}{|l|}{ Bermuda } \\
\hline British Virgin Islands & - & - & - & - & - & - \\
\hline Cayman Islands & - & - & - & - & - & - \\
\hline Cuba & 0.954 & 2 & 0.747 & 0.783 & 0.356 & 68 \\
\hline Dominica & - & - & - & - & - & - \\
\hline Dominican Republic & 0.995 & 1 & 0.710 & 0.713 & 0.477 & 104 \\
\hline Granada & - & - & - & - & - & - \\
\hline Haiti & - & - & - & - & 0.603 & 138 \\
\hline Jamaica & 0.995 & 1 & 0.715 & 0.719 & 0.430 & 93 \\
\hline Puerto Rico & - & - & - & - & - & - \\
\hline Saint Kitts and Nevis & - & - & - & - & - & - \\
\hline Saint Lucia & 0.991 & 1 & 0.725 & 0.731 & - & - \\
\hline Saint Vincent and the Grenadines & - & - & - & - & - & - \\
\hline Trinidad and Tobago & 0.985 & 1 & 0.763 & 0.774 & 0.371 & 73 \\
\hline Turks and Caicos Islands & - & - & - & - & - & - \\
\hline United States Virgin Islands & - & - & - & - & - & - \\
\hline
\end{tabular}

Source: United Nations Development Programme (UNDP), Human Development Report 2016: Human Development for Everyone, New York, 2016.

Note: All Latin America and the Caribbean countries available in the dataset (even if incomplete). 
Table A1.9

Latin America and the Caribbean: multidimensional poverty index (MPI), most recent year available

\begin{tabular}{|c|c|c|c|}
\hline & \multicolumn{3}{|c|}{ Multidimensional Poverty Index (HDR0) } \\
\hline & Year & $\begin{array}{c}\text { Headcount } \\
\text { (percentages) }\end{array}$ & Intensity ${ }^{\mathrm{a}}$ \\
\hline \multicolumn{4}{|l|}{ South America } \\
\hline Argentina & 2005 & 3.7 & 39.1 \\
\hline Bolivia (Plurinational State of) & 2008 & 20.6 & 47.0 \\
\hline Brazil & 2013 & 2.9 & 40.2 \\
\hline Colombia & 2010 & 7.6 & 42.2 \\
\hline Ecuador & $2013 / 2014$ & 3.7 & 39.6 \\
\hline Guyana & 2009 & 7.8 & 40.0 \\
\hline Peru & 2012 & 10.4 & 41.4 \\
\hline Suriname & 2010 & 7.6 & 43.1 \\
\hline \multicolumn{4}{|l|}{ Central America } \\
\hline Belize & 2011 & 7.4 & 41.2 \\
\hline Honduras & $2011 / 2012$ & 20.7 & 47.4 \\
\hline Mexico & 2012 & 6.0 & 39.9 \\
\hline Nicaragua & $2011 / 2012$ & 19.4 & 45.6 \\
\hline \multicolumn{4}{|l|}{ The Caribbean } \\
\hline Barbados & 2012 & 0.9 & 33.7 \\
\hline Dominican Republic & 2013 & 6.0 & 4.6 \\
\hline Haiti & 2012 & 50.2 & 48.1 \\
\hline Jamaica & 2010 & 3.7 & 38.8 \\
\hline Saint Lucia & 2012 & 0.8 & 34.5 \\
\hline Trinidad and Tobago & 2006 & 1.7 & 38.0 \\
\hline
\end{tabular}

Source: United Nations Development Programme (UNDP), Human Development Report 2016: Human Development for Everyone, New York, 2016.

a Weighted average number of deprivations poor people experience at the same time. 